Research Journal of Applied Sciences 14 (5): 165-169, 2019

ISSN: $1815-932 \mathrm{X}$

(C) Medwell Journals, 2019

\title{
Assessment of Senior Secondary School Student's Acquisition of Science Process Skills in Volumetric Analysis in Ondo State, Nigeria
}

\author{
Florence Obiageli Ezeudu, Esther Olubunmi Ikuelogbon, Anthonia Ebere Onah, \\ Uzoamaka P. Egbukwu, Nnonye Rebecca Ikegbunna and Oluchi Deborah Abaeme \\ Department of Science Education, University of Nigeria, Nsukka, \\ PMB 410001, Enugu State, Nigeria
}

\begin{abstract}
This study assessed the extent of senior secondary school student's acquisition of science process skills in volumetric analysis in Ondo State, Nigeria. Two research questions and one null hypothesis guided the study. The study adopted a descriptive survey design. A sample of 240 students was used for the study. The instrument used for data collection was a 20 -item rating scale. The research questions were answered using means while the hypothesis was tested using t-test statistic. The findings revealed that the level of senior secondary school student's acquisition of science process skills in volumetric analysis is low. Also, it was revealed that senior secondary school male students demonstrated high level of science process skills acquisition in volumetric analysis than female students. The need for training chemistry teachers on science process skills is recommended in order to make their teaching more practical oriented.
\end{abstract}

Key words: Science process skill, chemistry, volumetric analysis, gender, revealed, demonstrated

\section{INTRODUCTION}

Science deals with practical application of ideas through manipulation of materials in such a manner leading to discoveries (Yanper, 2007). The contributions of science to overall development of all nations cannot be over emphasized. Science holds an important position in the curriculum of Nigerian educational system Federal Republic of Nigeria (FRN) (Federal Republic of Nigeria, 2004). Therefore, the teaching and learning of science would require the acquisition of the science process skills. According to Ozgelen (2012), science process skills are thinking skills that scientists use to construct knowledge in order to solve problems and formulate results. Sevilay (2011) posits that the mastery of science process skills enables students to conceptualize at a much deeper level, the content they do know and equips them for acquiring content knowledge in the future. The skills facilitate learning in physical sciences and ensure active participation of diverse students in practical situations. Also, the acquired science process skills would help the learner in the meaningful exploration of the environment and place the learner at a position of solving world problems. Koray et al. (2007) opined that more scientific process skills featured in chemistry curriculum help students grasp concepts, adopt attitudes and improve skills related to chemistry class. For this reason, the acquisition of science process skills is the basis for scientific inquiry and the development of intellectual skills that are needed to learn chemistry concepts.
Chemistry is the scientific study of the interaction of chemical substances that constituted atoms or the subatomic particles: protons, electrons and neutrons (Adesoji and Oginni, 2012). Chemistry as a subject offered at senior secondary schools in Nigeria, takes a central position in science, technology and industry. Corroborating this Eke, asserts that any nation aspiring to be scientifically and technologically developed must have adequate level of chemistry education. The key role of chemistry in equipping the individual and developing the entire society is made clear in the chemistry curriculum at the senior secondary school level which include: to show chemistry and its link with industry, everyday life benefits, hazards and to provide a course which is complete for individuals not proceeding to higher institution (Federal Republic of Nigeria (FRN), (Federal Republic of Nigeria, 2004). Chemistry has been a prerequisite subject for most science oriented courses in tertiary institution and this makes it necessary that its teaching should be very effective for easy mastery of its various concepts such as volumetric analysis.

Tajudeen (2005) reported that senior secondary school students perceived volumetric analysis as a difficult concept to experiment. Therefore, poor achievement in volumetric analysis could be attributed to lack of acquisition of the appropriate skills by the students. In practical terms, Ajewole (1990), observed that student's achievement in volumetric analysis often fall below international standard; implying that their knowledge and understanding of science do not meet the

\footnotetext{
Corresponding Author: Esther Olubunmi Ikuelogbon, Department of Science Education, University of Nigeria, Nsukka, PMB 410001, Enugu State, Nigeria
} 
standard for competence in the global market. There has also been a persistent report about the poor achievement of students in science particularly in chemistry over the years (Oyedokun, 2012). According to Adeyemi (2008), of the total number of 43 students who sat for chemistry practical (volumetric analysis) in 2011,504 or $90.05 \%$ failed. Although, $9.95 \%$ passed, only 24 candidates or $0.05 \%$ passed at credit level and above. In 2012 of the 97,595 students that sat for the paper, only 8,109 or $7.57 \%$ passed at credit level and above while $70.48 \%$ failed. Moreover, in 2013 out of the 44,950 students that sat for the paper, 2,577 or $5.32 \%$ had credit and above 3,432 or $7.09 \%$ had passed while 37,973 or $70.39 \%$ failed, respectively. This is manifested in the low percentage of students who make the required credits at the school certificate examination. By implication, student's poor achievement in volumetric analysis could be as a result of inadequate laboratory materials required in chemistry practical. As such, the assessment of student's acquisition of science process skills in volumetric analysis remains in doubt. Likewise, there is no common consensus as to whether gender is another factor that affects the acquisition of science process skills in volumetric analysis and this tends to suggest that the science process skills of male and female chemistry students may vary. The problem of this study put in form of a question is: what is the extent of acquisition of science process skills in senior secondary school III students in Ondo Education zone of Ondo State? The general purpose of this study is to assess the level of Senior secondary school students acquisition of science process skills in volumetric analysis. Specifically, the study sought to:

- Determine the level of senior secondary school students acquisition of science process skills in volumetric analysis

- Ascertain male and female senior secondary school students level of acquisition of science process skills in volumetric analysis

Research questions: What is the level of senior secondary school chemistry student's acquisition of science process skills in volumetric analysis?

What is the difference between senior secondary school male and female chemistry student's level of acquisition of science process skills in volumetric analysis?

\section{Hypothesis:}

- $\mathrm{Ho}_{1}$ : there is no significant difference between the mean level of male and female senior secondary school chemistry students acquisition of science process skills in volumetric analysis

\section{MATERIALS AND METHODS}

This study adopted a descriptive survey design. According to Nworgu (2006), descriptive survey is a type of study which aims at collecting data and describing in a systematic manner, the characteristic features or facts about a given population. Thus, the researchers see it necessary to use this design because a representative sample of the student population was used. The study was carried out in Ondo education zone of Ondo State, Nigeria. Ondo education zone was chosen for this study because of the observed poor achievement of students in chemistry and its related concepts in the zone. The population of this study was 1,712 students which comprised of 879 males and 833 female SSIII Chemistry students of the 42 public senior secondary schools in the zone. The sample size of the study was 240 SS3 Chemistry students (130 males and 110 females) selected in line with Nwana's criteria that if the population of a study is in a few hundreds (Nwana, 1982) a 40\% or more will do if many hundreds a $20 \%$ sample will do and several thousand a $5 \%$ or less will do. The sample was selected using simple random sampling technique. Eight schools were sampled out of the 42 public secondary in the zone. All the SSIII chemistry students in the sampled schools were used for the study. The researchers used data collection instrument titled Science Process Skills Rating Scale (SPSRS) which consisted of a 20 -item rating scale. The SPSRS items were created from SSIII West African Examination Council (WAEC., 2013) alternative to practical chemistry questions of 2014 . The twenty items rating scale was designed to assess the extent of acquisition of science process skills among senior secondary schools III chem istry students. In line with the chemistry curriculum of the Federal Ministry of Education in Nigeria the scale was organized around the concept of volumetric analysis (acid-base titration). The SPSRS was designed to assess student's science process skills acquisition in volumetric analysis on five-point rating scale thus: Excellent $(E)=5$, Very Good $(V G)=4$ Good $(\mathrm{G})=3$, Fair $(\mathrm{F})=2$ and Poor $(\mathrm{P})=1$. The SPSRS was subjected to face validation by three experts from the department of science education, University of Nigeria, Nsukka. These experts validated the instrument in terms of clarity of language, appropriateness and adequacy of the items in measuring what they are supposed to measure. For instance, the initial two-point rating scale was change to five-point rating scale. Thirty copies of the instrument SPSRS were trial tested on 30 SSSIII students from public senior secondary schools in Owo/Ose Education zone of Ondo State, Nigeria which is outside the area of this study but share similar characteristic with the study zone. The Cronbach alpha technique was used to determine the internal consistency. The reliability coefficient of 0.77 was obtained. Likewise, Kendall's W coefficient of concordance was use to conduct inter-rater 
Res. J. Applied Sci., 14 (5): 165-169, 2019

reliability among four experienced chemistry teachers. The SPSRS was used to assess the senior secondary school III student's acquisition of the five science process skills under study in the eight schools that were drawn for the study. The chemistry teachers in each school (research assistant) were instructed for two days on how to use the rating scale by the researchers for the study. The chemistry students were divided into five groups in each school, so that, the research assistants could conveniently distribute and retrieve the copies of the questionnaires from the students. The students in each group were invited into the chemistry laboratory and allowed forty minutes to demonstrate their skills in respect to instructions on the study. The data collected were analyzed using inferential statistics. Mean and Standard Deviation (SD) were employed in answering the research questions. The decision on mean is based on the following range of values set by the researchers: $0.50-1.49$-poor, 1.50-2.49-fair, 2.50-3.49-good, 3.50-4.49-verygood and 4.50-5.00-excellent, respectively. The t-test statistics was used to test the null hypothesis at 0.05 level of significance. This study was approved by the Research Ethics Committee at the Department of Science Education, University of Nigeria, Nsukka.

\section{RESULTS AND DISCUSSION}

Research question one: What is the level of senior secondary school chemistry student's acquisition of science process skills in volumetric analysis?

The Table 1 shows the mean and standard deviation of student's level of science process skills acquisition in volumetric analysis. The data on Table 1, according to their overall mean scores of 2.44 and standard deviation of 0.96 , it shows that the students demonstrated low skills acquisition in volumetric analysis.

Research question two: What is the difference between senior secondary school male and female chemistry student's level of acquisition of science process skills in volumetric analysis?

Table 2 shows the difference between senior secondary school male and female student's level of acquisition of science process skills in volumetric analysis. From the Table 2, male students have mean rating of 2.64 with standard deviation of 0.31 while female students have mean of 2.49 with standard deviation of 0.40 in the Table 2. This data implies that male students demonstrated good science process skills compared to female students. Therefore, the table revealed that there is difference between senior secondary school male and female chemistry student's level of acquisition of science process skills in volumetric analysis.
Table 1: Mean scores of students and standard deviation on the level of science process skills acquisition in volumetric analysis $(\mathrm{N}=240)$

\begin{tabular}{lccl}
\hline Skills & $\overline{\mathrm{X}}$ & $\mathrm{SD}$ & Remarks \\
\hline Observing skills & 2.12 & 0.82 & Fair \\
Measuring skills & 2.38 & 1.06 & Fair \\
Experimenting skills & 2.42 & 1.04 & Fair \\
Communicating skills & 2.54 & 1.02 & Good \\
Classifying skills & 2.58 & 0.86 & Good \\
Overall mean & 2.44 & 0.96 & Fair \\
\hline
\end{tabular}

Table 2: Mean scores between male and female students on science process skills acquisition in volumetric analysis $(\mathrm{N}=240)$

\begin{tabular}{llll}
\hline Genders & $\overline{\mathrm{X}}$ & $\mathrm{SD}$ & Remarks \\
\hline Male & 2.64 & 0.31 & Good \\
Female & 2.49 & 0.40 & Fair \\
\hline
\end{tabular}

Hypothesis: There is no significant difference between the mean level of male and female senior secondary school chemistry students acquisition of science process skills in volumetric analysis.

Table 3 shows the summary of the t-test analysis. From Table 3, the calculated t-value at 238 degree of freedom and 0.05 level of significance is 2.98 . Given the calculated value of $\mathrm{t}=2.98$ and is significant at 0.03 ; the value is also significant at 0.05 . Therefore, the hypothesis was rejected. Hence, there is significant difference between the mean level of male and female senior secondary school chemistry students acquisition of science process skills in volumetric analysis.

The current study focused on the assessment of senior secondary school chemistry student's acquisition of science process skills in volumetric analysis. The results obtained from research question one revealed that the level of senior secondary school chemistry student's acquisition of science process skills in volumetric analysis is low. This implies that students demonstrated low skills acquisition in such skill areas like observing, measuring and experimenting. The result is in line with Nejla (2013) who found that students have low science process skills acquisition and this has negative effects on algorithmic problem-solving of students. The finding corroborates the study by Oloyede (2012) who reported a positive relationship between formal reasoning ability and acquisition of science process skills, formal reasoning and chemistry achievement. Jack (2011) agreed that science process skills are very fundam ental to science teaching at the secondary school level of education. Ogunniyi (2000) revealed that student's low acquisition of science process skills could result to their failure in chemistry. Therefore, the extents of science process skills acquisition determine student's achievement in chemistry concepts such as volumetric analysis.

The results obtained from research question one show that senior secondary school male chemistry students demonstrated high level of science process skills 
Res. J. Applied Sci., 14 (5): 165-169, 2019

Table 3: Independent t-test analysis of male and female chemistry students on science process skills acquisition in volumetric analysis ( $\mathrm{N}=240)$

\begin{tabular}{lccccccc}
\hline Genders & $\mathrm{N}$ & $\overline{\mathrm{X}}$ & $\mathrm{SD}$ & $\mathrm{df}$ & $\mathrm{t}$-cal & Sig-t & Remarks \\
\hline Male & 130 & 2.64 & 0.31 & 238 & 2.98 & 0.03 & Rejected \\
Female & 110 & 2.49 & 0.40 & & & & \\
\hline
\end{tabular}

acquisition in volumetric analysis than female students. Therefore, there is significant difference between the mean level of male and female senior secondary school chem istry students acquisition of science process skills in volumetric analysis. The result is in line with Ezeudu and Theresa (2013) who shows that male students achieved significantly better than the female students in both urban and rural schools. It is also in agreement with Bosede (2010) who stated that gender influences student's academic achievement in volumetric analysis. Likewise, Jegede observed that the female students show higher anxiety towards carrying out volumetric analysis in senior secondary schools than male students. The finding corroborates the study by Sempala (2005) who reported that there is disparity between male and female student's performance in sciences. Also, Oludipe (2003) indicated that girls show unfavorable attitudes toward science learning compared to boys in senior secondary schools.

\section{CONCLUSION}

In conclusion, the level of senior secondary school chemistry student's acquisition of science process skills in volumetric analysis is low. Senior secondary school male chemistry students demonstrated high level of science process skills in volumetric analysis than female students. There is significant difference between the mean level of male and female senior secondary school chemistry student's acquisition of science process skills in volumetric analysis.

\section{RECOMMENDATIONS}

Chemistry teachers should present science process skills in clearer terms, starting from simple to complex to enable chemistry students to acquire them.

Chemistry teachers should direct more attention to female chemistry students for improvement on their science process skills acquisition to enhance their achievement in chemistry.

Government/Ministry of Education and professional organizations like STAN should organize workshops, seminars and conferences for chemistry teachers to update them on science process skills acquisition. The need for training chemistry teachers on science process skills is recommended in order to make their teaching more practical oriented.

\section{REFERENCES}

Adesoji, F.A. and A.M. Oginni, 2012. Students aptitude indices as predictors of learning outcomes in chemistry. Br. J. Arts Soc. Sci., 8: 174-182.
Adeyemi, T.O., 2008. The influence of class size on the quality of output in secondary schools in Ekiti State, Nigeria. Am. Eurasian J. Sci. Res., 3: 7-14.

Ajewole, G.A., 1990. Effects of guided discovery and expository instructional methods on students transfer of learning. J. Sci. Teachers Assoc. Niger., 26: 59-66.

Bosede, A.F., 2010. Influence of sex and location on relationship between student problems and academic performance. The Social Sci., 5: 340-345.

Ezeudu, F.O. and N.O. Theresa, 2013. Effect of gender and location on student's achievement in chemistry in secondary schools in Nsukka local governmentarea of Enugu State, Nigeria. Res. Humanities Social Sci., 3: $50-55$.

Federal Republic of Nigeria, 2004. National Policy on Education. 4th Edn., NERDC Press, Lagos, Nigeria.

Jack, G.U., 2011. The influence of identified student and school variables on students science process skills acquisition. J. Educ. Pract., 4: 16-23.

Koray, O., M.S. Koksal, M. Ozdemir and A.I. Presley, 2007. The effect of creative and critical thinking based laboratory applications on academic achievement and science process skills. Elementary Educ. Online, 6: 377-389.

Nejla, O., 2013. Exploring effects of high school students mathematical process skills and conceptual understanding of chemical concepts on algorithmic problem solving. J. Res. Educ., 4: 11-14.

Nwana, O.C., 1982. Introduction to Educational Research for Student Teachers. Heinemann Publisher, Ibadan, Nigeria,

Nworgu, B.G., 2006. Educational Research: Basic Issues and Methodology. 2nd Edn., University of Nigeria, Nsukka, Nigeria,

Ogunniyi, M.B., 2000. Primary School, Science and Methods. Heinemann Educational Books, Ibadan, Nigeria,

Oloyede, S.O., 2012. Secondary school students level of understanding of selected chemistry concepts in Osun State, Nigeria. J. Afr. Educ. Res. Network, 6: $32-72$.

Oludipe, B.D., 2003. Peer tutoring-assisted instruction: An intervention for increasing senior secondary school students achievement in Physics. Afr. J. Educ. Res., 9: 42-48.

Oyedokun, M.R., 2002. Identification of difficult topics in the senior secondary school certificate biology syllabus as perceived by students. Niger. Teach. Today, 10: 110-120. 
Ozgelen, S., 2012. Student's science process skills within a cognitive domain framework. Eurasia J. Math. Sci. Technol. Educ., 8: 283-292.

Sempala, F., 2005. Gender differences in performance of chemistry practical skills among senior six students in Kampala District. Ph.D Thesis, University of Florida, Florida, USA.

Sevilay, K., 2011. Improving the science process skills: Ability of science student teachers using I diagrams. Eurasia J. Phys. Chem. Educ., 3: 26-38.
Tajudeen, C.B., 2005. Enhancing science process skills acquisition in Volumetric analysis using co-operative learning strategy. J. Chem. Panel Workshop, 37: 30-34.

WAEC., 2013. The West African senior school certificate examinations. West Africa Examination Council, Lagos, Nigeria.

Yanper, J., 2007. Teaching Science in the Primary Classroom. 2nd Edn., TJ International, Padstow, England, UK., 